Vol. 5, No. 2, 2018

https://doi.org/10.23939/eem2018.02.027

UDC 658.012

S. Babinska

$\mathrm{PhD}$ in Economics, Assistant

Lviv Polytechnic National University

\title{
EVALUATION OF ECONOMIC EFFICIENCY AND DIRECTIONS OF IMPROVEMENT OF INFORMATION PROVISION OF INNOVATIVE PROJECTS
}

\begin{abstract}
The process of information provision of innovative projects is complex, since it requires the application of certain skills of a methodological and technical nature. The design and implementation of innovative projects begins with the collection and processing of information about the external environment and internal processes. Using at this information systems raises the effectiveness of their implementation. However, him permanent improvements will result in the successful implementation of innovative projects.
\end{abstract}

Key words: information, information provision, innovative projects.

\section{Problem statement}

Efficiently constructed information provision of innovative projects increases the success of managerial decisions, contributes to achieving the goals and objectives of innovative projects, reducing routine work etc. Formation and use of information provision of innovative projects is a complex process, however, it needs to be continuously improved. This will lead to the successful implementation of innovation projects and innovation activity in general.

The essence of improving of information provision of innovative projects can be the creation of new or modernization of existing systems of information provision of innovative projects. It needs to be done systematically in order to ensure the proper level of information quality.

\section{Analysis of recent research and publications}

Research questions of the formation and use of information provision was provided by such scholars as: J. Akerlof, R. Barkley, I. Bosak, L. Walras, N. Georgiadi, C. J. Arrow, V. Evdokimov, M. Yermoshenko, I. Korneev, R. Neumann,
V. Ogienko, E. Paliga, M. Spence, J. Stiglitz, J. Tyrol, F. Hayek, S. Chistyakov, M. Chumachenko, N. Shpak, A. Shanthret and others. Despite the considerable attention of scientists to the study of innovation projects and the necessary information with this, the question of evaluation economic efficiency and possible directions of improvement of informational provision of innovative projects remain insufficiently studied and need further research.

\section{The aim of this research}

Improve the approach to evaluating efficiency and identify possible ways to improve information provision in the process of design and implementation of innovative projects.

\section{Material presentation}

For effective functioning system of information provision must be integral, with the automation of the processes of collecting, processing, storing and transmitting information. However, for today exist low disadvantages in the process of informational provision of innovative projects:

- absence the only information space where was in all information on innovation activity and which would provide access to national information resources and exchange of information with the world;

- unsatisfactory material and technical and software (lack of software development, insufficient use of modern computer equipment, funds protection, technical capabilities, channels of information transmission, computer technology, insufficient attention to organizational and methodological support). The databases used do not 
meet the needs of users and do not take into account the specifics of the process of design and implementation of innovative projects. This indicates that it does not take into account such a factor as the possibility of adapting the information provision;

- insufficient personnel support. The low level of computer education in the staff leads to a shortage of skilled staff, which slows down the process of informatization;

- duplication and multiple processing of the same information at different managerial levels;

- lack of real and proper information interaction between stakeholders (significant costs time to receive an answer to a request, resulting in a reduction in the speed of action in extreme situations).

In the process of introducing and using information provision for design and implementation of innovative projects, there may be difficulties. In tabl. 1 discusses the main ones and provides directions for overcoming them.

Existing problems of information provision have a negative impact on the process of design and implementation innovative projects. After all on this process can affect both the surplus and the lack of information that is needed for the effective implementation of innovative projects.

At the initial stage of the implementation of the information provision, it is necessary to develop a system of indicators that would provide an immediate response to the deviations or violations that arise in the process of informational provision for design and implementation of innovation project and would enable the adjustment of certain indicators in accordance with the objective of the project.

As a result of the analysis of literary sources as well as the practice of machine building enterprises, in order to assess the level of information provision of innovative projects, it is recommended to use an integrated indicator of information provision for innovative projects that comprehensively characterizes the availability of necessary information at each stage of the life cycle of an innovation project and is determined as a result of the evaluation of level of information provision stage of design, implementation and completion of innovation projects with regard to their validity and criterion time.

To enter the time criterion it is advisable to differentiate the stage of design, implementation and completion. For a clear separation it is advisable to take into account the tasks of each stage of the life cycle. The design phase begins with the development of the strategy of the new product and lasts until the moment of business analysis, the implementation phase - from the formation of the brand product to commercialization, at the end of the serial production of the product begins the phase of completion of the main task is to complete the production of the product and the closure of contracts.

Table 1

\section{Basic difficulties in implementation systems information provision in the process of design and implementation of innovative projects and directions for overcoming them}

\begin{tabular}{|c|c|}
\hline Difficulties in introducing information provision & $\begin{array}{c}\text { Directions of overcoming difficulties when implementing } \\
\text { information provision. }\end{array}$ \\
\hline Level of training for the implementer & $\begin{array}{c}\text { It is necessary to involve qualified specialists who are } \\
\text { interested in implementation of information provision. }\end{array}$ \\
\hline Insufficient funding & $\begin{array}{c}\text { Increase the budget for financing information provision, } \\
\text { holding a tender for it's implementation or having a } \\
\text { financial strategy. }\end{array}$ \\
\hline Low skilled personnel & $\begin{array}{c}\text { Teaching the staff for advanced training, as employees are } \\
\text { not used to using new computer technologies. }\end{array}$ \\
\hline Lack of well-articulated tasks & $\begin{array}{c}\text { Availability in the participants clear objectives and } \\
\text { requirements for information provision. }\end{array}$ \\
\hline Informality business processes & Carrying out reengineering business processes prior to \\
implementation.
\end{tabular}

Note: systematized by the author on the basis of analysis [2] 


\section{Evaluation of economic efficiency and directions of improvement of information provision of ...}

Integral indicator the level of information provision of innovation projects we suggest to determine by the formula:

$$
\mathrm{I}_{\mathrm{IZIP}}(\mathrm{t})=, \sqrt[3]{P 1(\Delta t)^{1} \times P} 2(\Delta t)^{2} \times P 3(\Delta t)^{3}
$$

where, P1 - indicator of the level of information provision of the stage of development of innovation project, points; $\Delta \mathrm{t}_{1}-$ duration of the development stage, days; P2 - indicator of the level of information provision of the stage of implementation of innovation project, points; $\Delta \mathrm{t}_{2}-$ duration of the implementation stage, days; P3 indicator of the level of information provision of the stage of completion of innovation project, points; $\Delta \mathrm{t}_{3}-$ duration of the completion stage, days.

In turn, the level of information provision of the corresponding stage $(\mathrm{Pn})$ is calculated by the formula:

$$
\Pi_{\mathrm{n}}=\sum \mathrm{ZO}_{\mathrm{n}}=\sum\left(\mathrm{V}_{\text {кр. }} \times \mathrm{O}\right),
$$

where, $\mathrm{ZO}_{\mathrm{n}}-$ weight criterion use of a particular type of information at each stage of the life cycle of an innovation project; $\mathrm{O}$ - assessment of the use of a particular type of information at each stage of the life cycle of the innovation project, points.

Indicator the level of information provision for each stage of the life cycle of the innovation project (stage of design, stage of implementation and stage of completion) is defined as the sum of the weighted estimation of the use of each type of information at a particular stage, in turn, the weighted estimate is calculated as product weight of the criterion and assessments use of information.

The calculation of the integral indicator of the level of information provision of innovation projects was carried out at the following machinebuilding enterprises, such as: SP LLC "SferosElectron"; PJSC "Lviv Electrolumines Factory "Iskra", OJSC "Pasautoprom".

To determine the weight of each criterion was used method of expert assessments. Experts acted managers of all levels involved in the process of implementing an innovation project of investigated enterprises.

Total in the study took part 80 people. Poll was conducted to determine the weight of the criterion for each stage of the life cycle of the innovation project. Before of respondents were asked to determine the importance of using a specific type of information at the stage of design, implementation and completion of innovation project.

Rating was exhibited in points: 0 points information is not used; 0,5 points - information is partially used; 1 point - information is used in full.
Scale evaluation integral indicator of the level of information provision of innovation project:

- 0 - 0,25 - low level of information provision of innovation project, points;

$-0,26-0,5$ - average level of information provision of the innovation project, points;

- 0,51 - 0,75 - high level of information provision of innovation project, points;

$-0,76-1-$ very high level of informational provision of innovation project, points.

Definition of numerical gradation values of the scale done by assigning valid numbers with the preservation of the given relation.

Evaluation the level of information provision of innovation project at SP LLC "Sferos-Electron", PJSC "Lviv Electrolumines Factory "Iskra", OJSC "Pasautoprom" are shown in the table 2.

According to received results, the high level of information provision of innovation project is observed at SP LLC "Sferos-Electron" (0,55 points) because of the average level of information provision of the stage of design of innovation project $(0,45$ points) and high levels of implementation phase and completion of the innovation project, 0,55 points and 0,7 points, respectively. On PJSC "Lviv Electrolumines Factory "Iskra" - the average level of information provision of innovation project $(0,41$ points) due to the low level of information provision at the stage of design of innovation project $(0,25$ points). At OJSC "Pasautoprom", the average level of information provision of innovation project $(0,27$ points) is also observed due to the average level of information provision for the stages of design and implementation of the innovation project and the low level of completion.

Using such a system of evaluation allows you to identify "problem areas" and take the necessary measures to improve the information provision of innovation project. The essence of improving the information provision of innovative projects can be to create new or upgrade existing systems. Him must be carried out systematically in order to ensure an adequate level of quality. The improvement of information provision system should be based on new information technologies, means of computer and communication technology, which in turn will allow to increase the productivity of the participants of the implementation of the innovation project, optimize the use of resources and costs, accelerate workflow, accelerate problem solving, etc. After all a prerequisite for the effective implementation of innovative 


\section{Babinska S.}

projects are:implementation a set of activities for the creation systems information provision, access to it for interested persons, monitoring of the quality of information provided to users;

implementation necessary measures of information security;

increase qualification and retraining of the participants of implementation of innovation project; increasing the level of information provision of each participant in the implementation of innovation project;

development of general information infrastructure.

Therefore, focusing on improving the effectiveness of information provision, it is necessary:

create an information base which will contain legislative and regulatory acts on innovation activity, specialized periodicals and other informational materials;

use this system where it is automated functions search, collection, processing, storage of information with using computer hardware and special software;

form the system of informational provision of innovative projects taking into account interna- tional experience to solve problems that arise in the process of project implementation with the use of modern information technologies;

create information and communication technologies and networks for access to information resources for participants of innovative projects.

Experts acted the manager of all levels of such machine-building enterprises: SP LLC "Sferos-Electron", PJSC "Lviv Electrolumines Factory "Iskra", OJSC "Pasautoprom". Total in the study took part 50 experts. Before respondents was put the task of choice the west improvement that they think is most effective. The results of the survey are summarized in table 3 .

The largest share among respondents $(48 \%)$ believe that the most effective measure for improving information provision of innovative projects is the creation of a single information space. The only information space is to create a set of databases, information and communication systems and networks that operate in accordance with the general rules and principles, ensuring the exchange of information between citizens, organizations, while meeting the information needs of users.

Table 2

Results of calculation of integral index of level of information provision of innovative projects at machine-building enterprises

\begin{tabular}{|c|c|c|c|c|}
\hline Enterprises & \multicolumn{4}{|c|}{ Value indicators } \\
\cline { 2 - 5 } & $\mathrm{P} 1$ & $\mathrm{P} 2$ & $\mathrm{P} 3$ & $\mathrm{I}_{\mathrm{IZIP}}$ \\
\hline SP LLC “Sferos-Electron” & 0,45 & 0,55 & 0,7 & 0,55 \\
\hline PJSC “Lviv Electrolumines Factory "Iskra” & 0,25 & 0,5 & 0,59 & 0,41 \\
\hline OJSC "Pasautoprom” & 0,29 & 0,43 & 0,15 & 0,27 \\
\hline
\end{tabular}

Note: calculated by the author on the basis of data enterprises

Table 3

Possible measures to improve the information provision of innovative projects at machine-building enterprises

\begin{tabular}{|l|c|}
\hline \multicolumn{1}{|c|}{$\begin{array}{c}\text { Measures to improve the information provision } \\
\text { of innovative projects }\end{array}$} & $\begin{array}{c}\text { Recognized the event as } \\
\text { expedient (\%) }\end{array}$ \\
\hline Creation of a single information space & 48 \\
\hline $\begin{array}{l}\text { Setting up of information communications in the process of implementation of } \\
\text { innovative projects }\end{array}$ & 29 \\
\hline Increase the level of software & 10 \\
\hline Implementation of document management system & 6 \\
\hline Implementation of an automated internal reporting system & 5 \\
\hline Introduction systems of balanced indicators & 2 \\
\hline
\end{tabular}

Note: compiled by the authors 


\section{Evaluation of economic efficiency and directions of improvement of information provision of ...}

For debugging information communications in the process of implementing innovative projects gave their voice $29 \%$ of experts. In this case, the communication system is a direct (from the implementer of the innovation project to participants) and feedback (from the participants to implementer of innovation project). One of the possible options for improving the information provision of innovative projects at the enterprises of the machine-building industry is set-up such connections, which will improve information communications and ensure compliance basic requirements both for information and for information provision.

The smallest share of the proposed measures were:

increase equal software (10\%);

implementation of document management system $(6 \%)$;

introduction of automated systems compilation of internal reporting (5\%);

the introduction of a balanced indicator system $(2 \%)$.

Under the software understand a set of programs for the processing of information and software documents that are required for the operation of these programs. Implementation of such a system will allow to reduce the lack of necessary skills and knowledge of personnel in working with documents, ensure comparability of indicators of the reporting period with the past and the adequacy of information provision, etc. With the help of an automated financial reporting system, the implementer and the participants of the innovation project can obtain the necessary information on the economic activity of the company, which will be organized and received at the right time. Such a system will increase the level of awareness of participants at any given time. The system of balanced indicators is based on the indicators of financial and non-financial nature, their calculation and analysis, and the provision of practical recommendations for improving the results of a particular indicator taking into account the sectoral peculiarities of the machine-building industry.

Taking into account the views of the authors $[1 ; 3 ; 4 ; 5 ; 6 ; 7 ; 8 ; 9]$ and on the basis of the survey conducted it can be argued that the main ways of improving information provision of innovative projects for machine-building enterprises are:

establishment of an effective exchange of innovative information at the interstate level;

creation of mechanisms for realization of the right of access to interested persons to the necessary information; adaptability and the possibility of development system of information provision of innovative projects; automation of information provision of innovative projects should cover all stages of it's life cycle;

only rules in the information base for the collection, processing, storage, use and transfer of information; introduction of the latest computer information technologies; use of powerful and efficient computer networks;

application of the system of electronic document management (automation of the document circulation process), which will ensure the automated movement of documents and constant control over the passage of documents, has a significant impact on reducing the timing of preparation and decision-making;

combination of different forms presentation of information what provide users with up-to-date and complete information and provide them with the opportunity to view, copy, or print the necessary information sources;

increasing the manageability of the information provision of innovative projects at the expense of speed information flows, reduction of mistakes when making managerial decisions at the expense of use actual and timely information;

the use of special means of protection and information security.

It is important to note that one of the ways to improve information provision both in innovation activities in general and in innovation projects in particular is creation of a single information space, which will enable to significantly increase the degree of interaction of remote offices, affiliates, representative offices. Integrated and stored corporate information is in the system, not in the head of employees. When a worker is released or transferred to another unit, his knowledge related to the processing of information is stored in the database and can be used by other employees who came to their place. Combining knowledge of employees in such a corporate system gives a synergistic effect, which can lead to high results. Information entered at any level should be accessible to all users of the information system, should to be executed the principle one-time introduction. When creating a national information space important is his interaction with the world.

The effectiveness of the formation and use of information provision for innovation projects 


\section{Babinska S.}

depends on it's interaction with the information provision system in the information market, existing and potential information resources, state information provision and information space. Therefore, the important point is the formation of an adequate information infrastructure of machinebuilding enterprises and interaction with the market players. Under the informational space should be understood the information base necessary for making managerial decisions, analysis, control and regulation of financial and economic activity of an industrial enterprise [4]. Such a system should provide for the exchange of information at all levels of government. Example, in our country there is no single center that collects and analyzes information from enterprises that carry out innovative activities. No less an important point is the interaction of the information provision system with the Internet, support for the Web-interface, integration with other external systems, such as: "Client-Bank", electronic document flow, automated design, management of technological processes, etc. Such interaction will reduce the time spent on implementation user queries. For this purpose the formation and use of information provision system should be based on the use of software tools, information and communication technologies, network infrastructure, etc.

Effective formation and use of information provision for design and implementation of innovative projects can lead to a shorter time for office workers working with documents (contracts, accounts, overhead, letters, etc.) due to reduced time on routine processing of documents. By conducted by estimated the total average time spent by office workers on unproductive processing of documents is more than $60 \%$. At the same time, some of the workers spend almost all their working time on these operations [3, p.45].

\section{Conclusions}

For evaluation the level of information provision of innovation project it is proposed to carry out the calculation of the integral indicator of the level of information provision of innovative projects, which enables to formulate a clear conclusion for the adoption of objective managerial decisions, to take into account the interests of all stakeholders, identify "problem areas" and the risks inherent in the stages of the life cycle of innovation project and participants in the implementation of the innovation project. Improving the information provision of innovative projects will not only save time for participants, but also increase the efficiency of their work and accuracy of information, reduce risk and reduce uncertainty. As a result of the research carried out at the machine-building enterprises (SP LLC "SferosElectron", PJSC "Lviv Electrolumines Factory "Iskra", OJSC "Pasautoprom") with identification of possible measures to improve the information provision of innovative projects established the most effective ones are: the creation of a single information space $(48 \%)$ and the establishment of information communications (29\%), less effective: increasing the level of software $(10 \%)$; implementation of document management system (6\%); implementation of the automated internal reporting system (5\%); introduction of a balanced indicator system (2\%). Conduct improvement of information provision can be achieved either through the creation of new or modernization of existing systems. It must be carried out systematically in order to ensure the proper level of information quality.

\section{References}

1. Yeltsov V. O. (2010) Of improvement of information provision of judicial activity. - Law and Safety № 5, p. 99-103, [Electronic resource] - Access mode: http://nbuv.gov.ua/UJRN/Pib_2010_5_24

2. Zhilinska L. O. (2014) Improvement of subsystem of information provision at the industrial enterprise. State and regions. Series: Economics and Business, [Electronic resource] - Access mode: http://nbuv.gov.ua/UJRN/drep_2014_5_15

3. Batyuk A. E., Dvulit Z. P., Obel'ovskaya K. M. and other (2009) Information systems in management. Lviv: National University "Lviv Polytechnic", "Intellect-West".

4. Ptitsina L. A. (2010) Optimizing the workflow of the enterprise to make managerial decisions. Economic space: Collection of scientific works №37, pp. 241-247.

5. Rotanov G. (2013) Improving the information provision of an industrial enterprise. - Collection of scientific works of Cherkasy State Technological University. Series: Economic Sciences. - 2013. Issue 34 (1), p. 61-64, [Electronic resource]-Access mode: http://nbuv.gov.ua/UJRN/Znpchdtu_2013_34(1)

6. Svetunkova $S . G$. Information management of competitiveness management. - Internet project "Encyclopedia of Marketing”, [Electronic resource] Access mode: http://www.marketing.spb.ru/read/m19/

7. Ptitsina L. A. (2011) Improving the formation of information provision for management system of enterprises of the baking industry of Ukraine, [Electronic resource] - Access mode: http://nbuv.gov.ua/UJRN/econupr

8. Yakovlev A. I. (2016) Means determination of efficiency from the creation and implementation of science-intensive products. - Economist № 3, [Electronic resource] - Access mode: http://nbuv.gov.ua/UJRN/econ_2016_3_6/ 